\title{
On the Role of Hebrew Grammars in the Western European Diaspora and the New World
}

\author{
Moisés Orfali
}

Many of the crypto-Jews who decided to leave Spain and Portugal were received by relatives or friends who had left before them and who provided the newcomers with information and assistance. However, once they left the Iberian Peninsula, these former crypto-Jews found that because they had a Catholic education, their Judaism was inadequate. A dual effort was made to solve this conflict in belief systems: Hebrew grammar texts were written in Spanish (Castilian) and in Portuguese in order to facilitate the study of the Hebrew language. The study of Hebrew was essential for regaining the vast body of traditional liturgy, lore, and Torah learning that had disappeared entirely during their stay in the Iberian Peninsula. ${ }^{1}$

It was necessary to smooth the progress of what Yosef Kaplan² and Miriam Bodian called the rejudaization of "the Nation,"3 that is, the collective enterprise to reeducate all émigrés from the Peninsula in the basics of Jewish belief and the origins of many Jewish daily practices, so that they could participate in the life of the community. The most essential tools for overcoming this Hebrew language deficit were grammar manuals as an aid to acquire the language that is considered indispensable for Jewish religious practice. Some of the spiritual leaders of the Western Sephardic diaspora, including Moseh Abudiente in Hamburg, Isaac de Abraham Uziel, Menasseh ben Israel, Salomon de Oliveyra,

1 On the Iberian Peninsula conversos' knowledge of Judaism, see Yosef Hayim Yerushalmi, From Spanish Court to Italian Ghetto. Isaac Cardoso-A Study in Seventeenth-Century Marranism and Jewish Apologetics (Seattle and London: University of Washington Press, 1981), 276-99; Yerushalmi, "Connaisance du judaïsme et préparation spirituelle chez les marranes revenues au judaïsme au cours du XVII' siècle," in Sefardica. Essais sur l'histoire des juifs, des marranes \& des nouveaux-chrétiens d'origine hispano-portugaise (Paris: Chandeigne, 1998), 235-54.

2 Yosef Kaplan discusses various aspects of the reeducation enterprise in Judios nuevos en Amsterdam: Estudios sobre la historia social e intelectual del judaísmo sefardí en el siglo XVII (Barcelona: Gedisa, 1996); Yosef Hayim Yerushalmi, "The Re-education of Marranos in the Seventeenth Century," in The Third Annual Rabbi Louis Feinberg Memorial Lecture in Judaic Studies, March 26, 1980 (Cincinnati: University of Cincinnati, 1980), 7-11.

3 See Miriam Bodian, Hebrews of the Portuguese Nation: Conversos and Community in Early Modern Amsterdam (Bloomington: Indiana University Press, 1997), 96ff.

(C) MOISÉS ORFALI, 2019 | DOI:10.1163/9789004392489_018

This is an open access chapter distributed under the terms of the prevailing CC-BY-NC License at the time of publication. 
and Mosse Rephael d'Aguilar in Amsterdam, and Isaac Aboab da Fonseca in the New World (Recife), set out to produce the needed texts.

We will deal with the trends spurred by the authors of those Hebrew grammars in terms of the aims of their works: acquisition of passive knowledge of Hebrew only or active mastery of the Holy Tongue. Special attention will be paid to the goal of Rabbi Isaac Aboab da Fonseca whose unpublished Hebrew grammar titled Melekhet ha-Diqduq was meant to teach biblical Hebrew, versus Baruch Spinoza who wrote his Compendium grammatices lingua hebraeae with the objective of inculcating a kind of secularized Hebrew by transforming its rules and practices into the form of a natural language and not as a "Holy Tongue." Spinoza summarized the aim of his work by stating that this grammar was meant to be used by "those who desire to speak Hebrew and not just chant it."

\section{Hebrew Grammar Books}

The Hebrew grammar written by Aboab's educator, Isaac de Abraham Uziel (? Fez-1622 Amsterdam), titled Ma'ane Lashon, was the first Hebrew publication printed in Amsterdam by Menasseh ben Israel (1604-1656) in 1627. This grammar contains a list of Hebrew grammatical terms with their Spanish equivalents in Hebrew script. ${ }^{4}$ In 1633, Moseh Abudiente (1602-1688) published a Hebrew grammar in Portuguese in the city of Hamburg titled: Gramatica hebraica. Parte Primeyra. Onde se mostram todas as regras nesessarias assim para a inteligençia da lingua, como para compor e escrever nella em proza e uerso com a elegançia e medida que conuem 5 (Hebrew Grammar. Part One. In which are given all rules necessary for understanding the language as well as for the composition and writing of it in prose and verse with the appropriate elegance and meter). Menasseh ben Israel claimed, in several of his publications, that he had

4 Isaac de Abraham Uziel was a teacher in the Talmudic school in Amsterdam. He taught both Isaac Aboab da Fonseca and Menasseh ben Israel. See Harm Den Boer, La Literatura sefardí de Amsterdam (Alcalá de Henares: Universidad de Alcalá, 1995), 37. He also wrote Libros Poéticos en Declaración de todos los Equívocos de las Sagradas Letras, in both Hebrew and Spanish, which was praised by Daniel Barrios who describes him as a great poet, a capable musician, and a distinguished mathematician. Joseph Serrano dedicated a poem to Uziel; it is inserted in the Temime Dere.

5 See Anthony J. Klijnsmit, “'Se qual o ouro entre todos os metáis.' Abudiente's Hebrew Grammar (1633)," in Die Sefarden in Hamburg. Zur Geschichte einer Mindehert, ed. Michael Studemund Halévy (Hamburg: Helmut Buske Verlag, 1994), 1: 319-74; Avi Elqayam, Sabbatean Millenarianism in the Seventeenth Century. A Study of Moshe Abudiente's Fin de los Dias (Los Angeles: Cherub Press, 2014), 51-52. 
written a Hebrew Grammar for his pupils, Libro yntitulado Safah Berurah, hoc est Labia clara da grammatica hebrea, in Hebrew and Portuguese. It was never printed, but circulated in manuscript copies. ${ }^{6}$ Only at the beginning of the twentieth century was Ets Haim able to acquire a manuscript of Menasseh ben Israel's grammar. This manuscript was copied by one of his pupils, Selomoh de Oliveyra (c. 1633-1708), as indicated on the title page. ${ }^{7}$ In 166o, Mosse Rephael d'Aguilar (c. 1625-1679) printed his Epitome da Gramatica Hebraica, por breve método composta para uso das escolas do modo que a ensina en portugues, in Portuguese ${ }^{8}$ which was intended for teaching Hebrew in schools, as appears from the title. This grammar has the same contents as Menasseh's grammar except for the syntax, which is not treated by d'Aguilar, but is less extensive. Selomoh de Oliveyra, a well-known copyist of Menasseh's Libro yntitulado Safah Berurah, created a manual of the Hebrew language called Yad LashonDal Sefatayim - Livro da Gramatica Hebraica e Chaldayca, which was printed in Amsterdam in 1689 by David Tartas. ${ }^{9}$ This grammar, similarly to d'Aguilar's, is intended for use in schools. It has a catechism-like appearance because the title of each chapter is a question.

6 In El Conciliador (Francaforte [Amsterdam], [s.i.] 1632), Prologo al lector, 4v, Menasseh Ben Israel refers to his Grammar saying "Y ansi hizimos el año passado la Gramatica Hebrea, diuidida en quatro libros, a la qual dimos nombre (safah berurah en letras hebreas) hoc est, Labia clara." He repeated this information in the Latin edition of The Conciliator (1633). In the second part of El Conciliador (Amsterdam: Nicolaas van Ravenstein, 1641), 3v, he adds that he began writing the grammar when he was seventeen years old and that it is in a manuscript, circulating from hand to hand. At the end of his life, in the edition of his Piedra gloriosa o de la estatua de Nebuchadnesar (Amsterdam: [s. i.], 1655), Menasseh says that he now intends to print the grammar, which he has perfected (con nuevas observaciones).

7 For information on the only known manuscript of this piece, see Lajb Fuks and Renate G. Fuks-Mansfeld, Hebrew and Judaic Manuscripts in Amsterdam Public Collections. II. Catalogue of the Manuscripts of Ets Haim / Livraria Montezinos, Sephardic Community of Amsterdam (Leiden: E.J. Brill, 1975), no. 326. Cf. Adri Offenberg, Menasseh ben Israel (1604-1657): Een Biografische Schets (Amsterdam: Menasseh ben Israel Instituut, 2000), 12-13. An extensive analysis of the grammar can be found in Anthony J. Klijnsmit, "Amsterdam Sephardim and Hebrew Grammar in the Seventeenth Century," Studia Rosenthaliana 22 (1988): 145-49; idem, "Some Seventeenth-Century Grammatical Descriptions of Hebrew," Histoire Epistémologie Language 12, no. 1 (1990): 81-85.

8 See Harm den Boer, Sephardic Editions, 1550-1820. Spanish and Portuguese Books Written and/ or published by Sephardic Jews of Early Modern Europe (Leiden: Brill, 2003-2005). See also Klijnsmit, "Amsterdam Sephardim," 149-153; idem, "Some Seventeenth-Century Grammatical Descriptions," 85-87.

9 Menasseh ben Israel gives his grammar the same title as a medieval grammar written by Abraham ibn Ezra in the twelfth century. A modern edition of Menasseh's work has been released, titled Yad Lashon, Diqduq (New York: Ch. Reich, 1994). On Selomoh de Oliveyra's Yad Lashon, see Klijnsmit, "Amsterdam Sephardim," 153-55. 
Anonymous grammar books for beginners were also printed. However, they were written in Hebrew. One useful instrument was David Cohen de Lara's lexical polyglot, titled Sive De Convenientiam vocabulorum Rabbinicorum Cum Graecis, \& quisbudam allis linguis Europaeis, published in Amsterdam in 1638. This is a synopsis of his Diccionario talmúdico rabinico, printed in Hamburg in 1668. According to the author, it took him twelve years to write this work.10 Two parallel pieces, one in Spanish and one in Hebrew, were added to this grammatical effort: the Ortografía castellana [...] a modo de Diálogo entre dos niños de la escuela, written by Abraham de Fonseca in $1663{ }^{11}$ and the Hebrew grammar titled Melekhet ha-Diqduq written completely in Hebrew, which Rabbi Isaac Aboab da Fonseca (1605-1693) compiled while he was staying in Pernambuco. He may have taught Baruch Spinoza $\left(163^{2-1677)}\right.$ the rudiments of Hebrew grammar prior to leaving for Brazil. Toward the end of his brief life, Spinoza wrote his Compendium grammatices linguae hebraeae (Amsterdam, 1677) in Latin. This is probably one of Spinoza's least known texts. It has been preserved as an unfinished text containing thirty-three chapters, and was not included $^{12}$ in the edition of the posthumous writings of Spinoza that were translated into Dutch and published in 1677 by Jarig Jelles under the title Nagelate Schriften. The reason for this omission was explained by Jelles in the preface to the book: "Apart from what we have already mentioned, Spinoza wrote an incomplete Hebrew grammar or treatise on letters in Latin. Although it has been highly praised by various experts who possess several copies, we did not believe that it would be useful to print it in Dutch here, but rather that

10 See Ángel Sáenz Badillos, "David de Cohen Lara y sus dos vocabularios rabínicos," in Los Judaizantes en Europa y la Literatura Castellana del siglo de Oro, ed. Fernando Díaz Esteban (Madrid: Letrúmero, 1994), 341-49.

11 Abraham de Fonseca's text is modeled after the Jesuit Francisco Pérez de Náxera's Orthographía castellana dividida en primera y segunda parte a modo de Diálogo entre dos niños de la escuela, published by Luis Sánchez in Valladolid in 1604. Náxera includes an Instrucción para enseñar bien a leer y escriuir in this work, in which he insists on the advantage of learning correct pronunciation in order to prevent orthographic mistakes. This Instrucción was included in Abraham de Fonseca's Ortografía.

12 The Compendium grammatices linguae hebraeae was included in the edition of Spinoza's complete works by C. Gebhardt (1925), but only three translations have ever been made of it: a Hebrew translation by Solomon Rubin, Compendium grammatices Linguae Hebraeae (Podgórze-Krakow: Drukiem I nakladem Józefa Plessnera i Ski., 1905); an English translation by Maurice Bloom, Hebrew Grammar (London: Vision Press, 1963) and a French translation by Joël Askénazi and Jocelyne Ashkénazi-Gerson, Abrégé de grammaire hébraique (Paris: J. Vrin, 19683). 
it should be left for the Latin edition, since Hebrew is rarely studied (by us), whereas Latin dominates." ${ }^{13}$

\section{Isaac Aboab da Fonseca's Grammar}

Aboab da Fonseca's elementary Hebrew grammar, Melekhet ha-Diqduq, is a practical introductory manual based on simple rules of Hebrew etymology, the parts of speech, conjugation, and declension tables. It exists in two eighteenthcentury manuscripts, both written by David Franco Mendes $(1713-1792)^{14}$ and dated on the title page with the Jewish year $5+2+400$. Some historians read this as $5402[=1641 / 42]$, since there is no indication "according to the abbreviated era." Others, including J.S. da Silva Rosa and A. Wiznitzer, read it as an abbreviated date, i.e., [5]407 $[=1646 / 7] .^{15}$ In any case, as Adri K. Offenberg already taught in his specific answer to the question of when and where Aboab's grammar was written, both dates suggest that Aboab composed his grammar in Brazil. ${ }^{16}$ For Offenberg, no matter how we read the date, "the text of the grammar was completed in Brazil four years before the famous poem Zekher 'Asiti le-Nifla'ot $E l$ [I made remembrance of the wondrous deeds of God ${ }^{17}$ ] and thus constitutes the first real Hebrew text written in the New World."18 Indeed,

13 De Nagelate Schriften van B.D.S.als Zedekunst, Staat-kunde, Verbetering van 't verstand, Brievben en Antwoorden uit Verscheide Talen in de Nederlandesche Gebracht (Amsterdam: Jan Rieuwertsz, 1677), §75.

14 Both manuscripts 47 E 4 and 47 C 12 repose in the Ets Haim library of the Portuguese Community of Amsterdam. See Fuks and Fuks-Mansfeld, Hebrew and Judaic Manuscripts, nos. 328 and 429. An English translation will appear in Moises Orfali, Isaac Aboab da Fonseca: Jewish Leadership in the New World (Eastbourne: Sussex Academic Press, forthcoming).

15 Jacob S. da Silva Rosa, "Iets over den Amsterdamschen Opperabijin Isaäc Aboab" Centraalblad voor Israelieten in Nederland 29 (1913): nos. 39-41 (list of Aboab's works, no. 2); Arnold Wiznitzer, "The Minute Book of Congregations Zur Israel of Recife and Magen Abraham of Mauricia, Brazil," Publications of the American Jewish Historical Society 42 (1953): 217-302; id., Jews in Colonial Brazil (New York: Columbia University Press, 1960), 169.

16 We owe these data to the innovative study of Adri K. Offenberg, "A Mid-SeventeenthCentury Manuscript of the (Unpublished) Hebrew Grammars of Menasseh Ben Israel and Isaac Aboab da Fonseca Recovered," Zutot 3 (2003): 104.

17 This thanksgiving narrative poem describing the horrors suffered by the Jews during the Portuguese attack on Dutch Recife has been considered as the earliest Jewish poem in the New World. The text was first published by Meyer Kayserling, "Isaac Aboab, the First Jewish Author in America," Publications of the American Jewish Historical Society 5 (1897): 129-31, http://jawutrecht.files.wordpress.com/2012/11/out-26.pdf; Kayserling, "Rabbi Yitzhak Aboab ha-Šeliši," Ha-Goren 3 (1902): 155-174.

18 Offenberg, "A Mid-Seventeenth-Century Manuscript," 106. 
Offenberg is right in deciphering the date on which Aboab finished his grammar based on the chronogram in both manuscripts taken from Lamentations 2:13: "O daughter of Jerusalem." The entire passage is read in synagogues on the Ninth of Av, the traditional day of mourning for the destruction of the Temple in Jerusalem and other torments. Four years earlier, the date on which the thanksgiving hymn was written fell exactly on August 1642, when Aboab was already appointed as rabbi in Recife.

This grammar text is a small treatise of only twelve pages, foliated alephwav, written on the rectos and versos in a Sephardic square and semi-cursive Hebrew hand with blind ruling. It was most probably written from memory and without the help of a reference library. Only once, in the seventh chapter when he deals with the Quadriliteral ${ }^{19}$ verbs, does he refer to the books of the leading Hebrew grammarians and their explanation concerning the reduplication of the third root consonant. Nevertheless, it is well-known that before leaving for northeast Brazil, he was in charge of teaching Talmud in the school of the Jewish community in Amsterdam where he also gave lessons in Hebrew grammar to students in the beit midrash. ${ }^{20}$ Moreover, from Kaplan's study on his library's catalogue we learn that thirty-two of the 524 Hebrew books that Aboab possessed were books on Hebrew grammar and different kinds of lexicography. ${ }^{21}$

Aboab da Fonseca apparently needed a grammar text as a teacher of Hebrew to young children and conversos in Recife. Its aim was to render the study of classical Hebrew simple and interesting. By keeping the grammatical discussion at a relatively unsophisticated level and explaining the rules from the point of view of ordinary speech, and how to correctly read the biblical text, he tried to make the book as serviceable as possible to those who want to study the language without a teacher. As mentioned, this was probably a textbook used by adults and children in Recife.

19 There are a number of verbs in Hebrew which have four root-letters as their basis, an

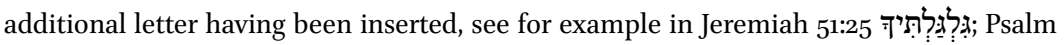

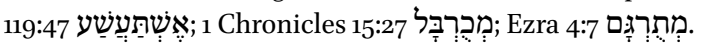

20 Chr. W. Pieterse, Daniel Levi de Barrios als geschiedschrijver van de Portuguees-Israelietiche Gemeente te Amsterdam in zijn "Triumpho del Govierno Popular" (Amsterdam: Scheltema \& Holkema 1968), 160.

21 Yosef Kaplan, "El perfil cultural de tres rabinos sefardíes a través del análisis de sus bibliotecas," in Familia, Religión y Negocio. El sefardismo en las relaciones entre el mundo ibérico y los Países Bajos en la Edad Moderna, ed. Jaime Contreras, Bernardo J. García García, and Ignacio Pulido (Madrid-Alcalá de Henares: Fundación Carlos de Amberes, 2002), 275; id., "The Libraries of Three Sephardic Rabbis in Early Modern Western Europe," [Hebrew] in Libraries and Book Collections, ed. Yosef Kaplan and Moshe Sluhovsky (Jerusalem: The Zalman Shazar Center for Jewish History, 2006), 234. 
Although Aboab's text clearly falls within the category of traditional elementary grammars, it contains several features that require a brief comment. The generous use of transliteration is meant to serve three purposes: enable the perception of Hebrew as a language and not an exercise in decipherment; remove the customary initial obstacle wherein the learner was required to master innumerable pages of rather abstract phonological and orthographic details before learning even a sentence of the language; and facilitate the memorization of the paradigms, where the essential features are, in my opinion, set in greater relief than in the conventional script. ${ }^{22}$

Aboab's grammar embraces the rules of Hebrew etymology, the parts of speech, and presents the morphology of the verb in a way that best exploits the underlying similarities of the various forms, regardless of the root type. This enables introduction of the most common verbs at an early point in the grammar and allows discussions of the derived "conjugations" to be unhampered by restriction to examples from sound roots. ${ }^{23}$ As much space as possible was allocated to the systematic treatment of noun morphology and to the verb with object suffixes. Simplification of this material, which was attempted in many elementary grammars, actually does a disservice to the learner. When he turns to his first page of unsimplified reading, he finds that what he should have learned systematically must instead be learned at random, inefficiently, and with rather great difficulty. Finally, special attention was given to an orderly presentation of prose syntax, beginning with characterization of the various types of individual clauses and ending with sequences of inter-related clauses.

In conclusion, Aboab seems to have made every attempt to make the grammar clear-cut and uncomplicated by being short and snappy and by giving examples for every grammatical explanation. The discussion is as straightforward as possible, for it is his intention that the text should also be useful to those who would study Hebrew without a teacher. It is written in the simplest possible lines, and yet enables the beginner to acquire great familiarity with the Hebrew

22 Hebrew grammar is essentially schematic and, starting from simple primary rules, it is possible to work out the main groups of word-building almost mathematically. In Aboab's grammar, when the reader is confronted with a new point he is usually referred to principles that have already been learned, which produce the required result when applied to the new problem. A typical example is the case of "Weak Verbs": these are explained rationally by the simple method of applying the ordinary rules governing "peculiar" letters to these verbs and thus working out the forms that they, respectively, assume.

23 It is not practicable to attempt to teach Hebrew grammar in all its details to beginners. It is more profitable to deal with the main principles and uses that should form the basis for more advanced study. On this account, Aboab endeavored to avoid references to the minute and manifold exceptions that appear in advanced Hebrew grammars as much as possible and practicable. 
biblical text. In nine chapters, without any introduction, he directly begins to deal with: [chapter one] the two kinds of Shewa, ${ }^{24}$ and the peculiarities of the guttural, palatal, labial, labio-dental, and interdental articulation of Hebrew letters; [chapter two] the Definite $\operatorname{Article}^{25}(h e), " H e$ " interrogative and "He" of surprise cases; [chapter three] the Consonants known as the begad kepat; ${ }^{26}$ [chapter four] the Parts of Speech: Noun, Verb and Particle; [chapter five] the Simple Active $(Q a l)$ and Simple Passive ${ }^{27}$ (Niph'al) stems; ${ }^{28}$ [chapter six] the Intensive Active $\left(\mathrm{Pi}^{\prime} \mathrm{e}^{29}\right)$, Intensive Passive $\left(\mathrm{Pu}^{\prime} \mathrm{al}^{30}\right)$ and the Causative

24 When there is a vowel-less letter at the beginning or in the middle of a word in a pointed text, then the sign: called Shewa (שוא), fills the gap under it. Aboab explains the four cases of Simple Shewa as well as the composite representation by shewa and short vowel together which gives rise to the term Composite Shewa.

25 The definite article of Hebrew closely corresponds to the definite article of English in usage and meaning. The basic form of the article is $h a$, plus a doubling of the following consonant. It is prefixed directly to the noun it determines.

26 Two sets of six sounds each are closely related to one another, both in sound and distribution. These are the six stops $b, g, d, k, p, t$ on the one hand, and their spirantized $b, g, d, k$, $p$ and $t$ on the other. Although no rule can be given for the choice between the sounds of one set and those of the other without important exceptions, Aboab's observations provide a safe guide for the majority of occurrences.

27 In some verbs, the Niph'al preserves a "middle" or "reflexive meaning." In such cases the significance of the Niphal oscillates between reflexive and passive. Isaac Aboab does not explain these situations.

28 The first of these has been called $Q a$, which means "light" by contrast with six stems which are derived from the same root. The verb פעל (pa'al) "did, performed" has been taken to serve as the prototype of the derived forms. Thus, the Simple Passive is the פפעל (niph'al), the Intensive Active is the פעל (pi'el), etc.

29 Pi'el verbs are regularly distinguished by a doubling of the second root consonant and stem patterns quite distinct from those of the Qal. Because the root of a Pi'el verb may not always occur as a Qal verb, it is sometimes difficult to define the meaning of a Piel form by direct comparison. Aboab does not present a representative collection of Piel verbs classified according to the meaning that may be assigned to the Pi'el as a derived type, i.e., secondary to some other form of the language [factitive (transitivizing), dominative and intensive. In addition to the three preceding categories, there are many Piel verbs whose origin is not clear. Some could doubtlessly be placed in the above classifications if Aboab had given the learner more data on the related Qal or nominal forms.

30 There is a passive counterpart that corresponds to every Piel verb which is known as the Pu'al. It is characterized, like the Pi'el, by a doubling of the middle root consonant. The pattern of vowels is more or less consistent throughout, with $u$ in the first stem syllable and $a$ (when not reduced) in the second. 
Active (Hiph'il ${ }^{31}$ ) stems; [chapter seven] the Causative Passive (Huph'a $\left.{ }^{32}\right)$, the Reflexive (Hitpa' ( $^{33}$ ) and Quadriliteral Verbs; [chapter eight] Strong Verbs and Weak Verbs; ${ }^{34}$ [chapter nine] Defective Verbs, ${ }^{35}$ Geminate Verbs and roots.

Aboab da Fonseca's unpublished Hebrew grammar manuscript may also be the first Hebrew text written in the New World. The approach taken in this grammar is to discuss nouns and particles first and then move on to verbs, presenting the essential basics of biblical Hebrew. It concentrates on the norms rather than the exceptions. It emphasizes tool-building and tool-use rather than memorization, so the readers and those who want to study the biblical text will have the basic tools necessary for dealing with most of the textual intricacies. It should be noted that the study of the biblical text in general constitutes a fundamental commandment in Judaism, and is valued as much as the total of all commandments. ${ }^{36}$ Maimonides, for example, considered the study of Hebrew- the language in which the Bible was transmitted-a commandment in its own right. ${ }^{37}$

Furthermore, Rashi and Maimonides (and other classical commentators on the Bible such as Abraham ibn Ezra and David Kimhi) were masters of the Hebrew language and serious students of grammar. These giant teachers, whose place among the sages of Israel of all times is indisputable, drew on their knowledge of Hebrew grammar for clarifying the meaning of the

31 Hiph'il verbs are, for the most part, causatives of the corresponding Qal. The distinctive mark of this conjugational type is prefixed $h$-, but because there is no present in the imperfect and the participle, one must also rely on vowel patterns to identify these forms and distinguish them from the Qal. Here too, Aboab does not mention the different meanings that can be assigned to the Hiph'il which may be grouped as follows: causative, permissive, denominative, and unclassified.

32 As in the Pi'el-Pu'al relationship, there is a passive counterpart of the Hoph'al type for each Hiph'il verb. The form is characterized by an $u$-vowel in the first stem syllable and $a$ in the second. The exact nature of the first vowel depends on the root type.

33 Hitpa'el verbs are relatively infrequent. They are distinguished by the prefixal element (h) it - and the doubling of the second root consonant. Hitpa'el verbs are intransitive and often have a reflexive or reciprocal meaning of relation to their active counterparts of the Qal, Pi'el, or Hiph'il type from the same root.

34 A verb is said to be weak when it deviates from the regular or normal type, due to (a) a guttural letter, (b) a quiescent letter, or (c) a letter, such as J, which is liable to assimilate, being among the root letters; because adjustments must then be made.

35 Often, when two kindred weak verbs with the same meaning are used, they are both $d e$ fective, i.e., do not occur in all forms. However, since those tenses and forms which are not in use in the one verb are generally supplied by the other, they mutually complete each other, and thus form an entire verb together, as it were, as in Latin fero, tuli, latum, ferre, etc., only in Hebrew the roots of these verbs are almost always closely related.

36 Maimonides, Mishneh Torah, Laws of Talmud Torah, 3: 3 .

37 Maimonides, Commentary on the Mishna, Avot 2: 1. 
Pentateuch text. ${ }^{38}$ Aboab, as a spiritual leader, follows them, trying to make Hebrew accessible not only by acknowledging grammatical tools for correctly understanding and reading the biblical text, but also by commenting on it by way of paraphrases. ${ }^{39}$

Spinoza's Compendium grammatices linguae hebraeae

Spinoza's grammar is the first Hebrew grammar written in Latin by an Amsterdam Sephardic Jew. He wrote it to explain the nature and properties of the language in which the Bible was written and in which its authors were accustomed to speak. He insisted that biblical study must follow the study of the nature and properties of the language in which most of the books of the Bible are written-the Hebrew language. Scriptural interpretation requires knowledge of this language in order to allow a straightforward study of Scripture: "And because all the writers, both of the Old Testament and the New, were Hebrews, it's certain that the history of the Hebrew language is necessary above all others, not only for understanding the books of the Old Testament, which were written in this language, but also for understanding those of the New. For though they've been circulated in other languages, nevertheless they are expressed in a Hebrew manner."40

Spinoza intended to write a Hebrew grammar in accordance with the rules of geometry in order to show the main rules of the Hebrew language and to demonstrate various changes in the language occasioned by its widespread use among all ancient Hebrew sects, which brought about many difficulties in the interpretation of the Bible:

38 There are numerous discussions of grammatical points in the classical Pentateuch commentaries of Rashi, Ibn Ezra, Rashbam, and Maimonides. See many examples in Ezra Zion Melammed's, Mepharshei Ha-Mikra (Jerusalem: Magnes Press, 1975), 1: 398-414; 2: 965-67.

39 In his Paráfrasis comentado del Pentateuco (Amsterdam: Iaacob de Cordova 5441 [1681]), Aboab says that the purpose of the Paraphrase in Spanish was as much for liturgical use as didactic and cultural. See Moisés Orfali, "Observaciones sobre el Paráfrasis comentado del Pentateuco de R. Isaac Aboab da Fonseca y sus fuentes" eHumanista 20 (2012): 21538; idem, "Paraphrastic Commentary to the Pentateuch by Isaac Aboab da Fonseca," in Portuguese Jews, New Christians and "New Jews": A Tribute to Roberto Bachmann, ed. Bruno Feitler and Claude Stuczinsky (Leiden-Boston: Brill, 2018), 334-6o.

40 Benedict de Spinoza, Tractatus Theologico-Politicus, in The Collected Works of Spinoza, ed. and trans. Edwin Curley (Princeton, NJ: Princeton University Press, 2016), chap. 8: 100 [p. 173] [hereafter, TTP]. 
Those who spoke and wrote Hebrew in ancient times left nothing to posterity regarding its foundations and teaching. Or at least we have absolutely nothing from them: no Dictionary, no Grammar, no Rhetoric. Moreover, the Hebrew Nation has lost all its marks of distinction and honor-this is no wonder, after it has suffered so many disasters and persecutions - and has retained only some few fragments of its language and of a few books. For almost all the names of fruits, birds, fish, and many other things have perished in the injustice of the ages. Again, the meaning of many nouns and verbs which occur in the Bible is either completely unknown or is disputed. We lack, not only all these things, but also and especially, a phraseology of this language. For time, the devourer, has obliterated from the memory of men almost all the idioms and manners of speaking peculiar to the Hebrew nation. Therefore, we will not always be able, as we desire, to find out with respect to each utterance, all the meanings it can admit according to linguistic usage. Many utterances will occur whose meaning will be very obscure, indeed, completely incomprehensible, even though they are expressed in well-known terms. ${ }^{41}$

In his Theologico-Political Treatise, Spinoza explained that he determined to examine the Bible in a careful, impartial, and unfettered spirit, making no assumptions about it and attributing no doctrines to it that he did not find clearly set down therein. A clear knowledge of the nature and peculiarities of the language of the Bible was essential for this, and a thorough understanding of the grammar was paramount. The interpretation "must contain the nature and properties of the language in which the books of Scripture were written, and which their Authors were accustomed to speak." ${ }^{42}$ His approach to the Bible seems to be scientific and at the same time properly religious, since he demands that one listen to what the biblical texts have to say, just as a natural scientist is careful to let factual data speak for themselves and not twist meanings according to preconceived notions. The study of the Bible should proceed by the use of the tool of natural reason, and in this effort the study of Hebrew grammar is, of course, most important. ${ }^{43}$

\footnotetext{
41 TTP, chap. 8: 106 [p. 180].

42 Ibid., chap. 8: 100 [p. 173].

43 The main features of Spinoza's Compendium grammatices linguae hebraeae, closely connected with his thought, were studied at length by Guadalupe González Diegez, Baruj Spinoza. Compendio de gramática de la lengua hebrea, Introducción, traducción y notas de [...] (Madrid: Editorial Trotta, 2005) and recently by Giovanni Licata, "Spinoza e la cognition universalis dell'ebraico. Desmitificazione e speculazione grammaticale nel Compendio di grammatical ebraica" Giornale di Metafisica 31 (2009): 625-61. See also
} 
The Bible may be Spinoza's only evidence for Hebrew as a spoken, natural language used by Jews in biblical antiquity. However, his goal was not to reveal the language's character as a sacred or mysterious system. Rather, it was to understand its structure as a big language. His is a work for those who desire to speak Hebrew, and not just chant it. ${ }^{44} \mathrm{He}$ intended his grammar to have two parts. Part One was intended to set out the letters of the Hebrew alphabet and to lay out the forms of verbs, nouns, and other parts of speech. Of special interest are the conjugations, declensions, vocalization, and so forth. Part Two would then give an account of sentence structure, syntax, and so forth.

Similarly to Aboab, Part One is composed of chapters, while there are none in Part Two. Those thirty-three chapters deal with: [chapter one] On the Letters and Vowels in General; [chapter two] On the Shape, Significance, Names, Classifications and Peculiarities of the Letters; [chapter three] On the Vowels; to wit, their shape, name, significance and properties; [chapter four] On the Accents; [chapter five] On the Noun; [chapter six] On the Inflection of Nouns from Singular into Plural; [chapter seven] On the Masculine and Feminine Gender; [chapter eight] On the Construct Case of Nouns; [chapter nine] On the Twofold Use of the Noun and of its Declension; [chapter ten] On the Preposition and the Adverb; [chapter eleven] On the Pronouns; [chapter twelve] On the Infinitive Nouns, the Variations of their Forms and Kinds; [chapter thirteen] On the Conjugation; [chapter fourteen] On Verbs of the First Conjugation Paradigms. Simple Active Verbs $\left(Q a l^{45}\right)$; [chapter fifteen] On Passive Verbs (Niph'al ${ }^{46}$ ); [chapter sixteen] On Active Intensive Verbs with a Dagesh (Pie ${ }^{47}$ ); [chapter seventeen] On Passive Intensive Verbs (Pu'al); [chapter eighteen] On the Derivative Active (Causative) Verb (Hiph'il); [chapter nineteen] On the Derivative Passive Verb (Hoph'al); [chapter twenty]

Baruch Spinoza, Hebrew Grammar (Compendium Grammatices Linguae Hebraeae), ed. and trans. Maurice J. Bloom (London: Vision Press Ltd., 1963); Philippe Cassuto, Spinoza hebraisant. L'hebreu dans le "Tractatus theologico-politicus" et le "Compendim grammatices linguae hebrae" (Leuven: Peeters Publishers, 200o); Compendium grammatices linguae hebraeae, in Spinoza, Complete Work, trans. Samuel Shirley, ed. with introduction and notes by Michael L. Morgan (Indianapolis and Cambridge: Hackett Publishing Company, Inc., 2002), 584-675. [Compendium grammatices linguae hebraeae hereafter in notes CGLH.].

That Spinoza aims at an active knowledge of Hebrew can be concluded from a remark in his treatment of the accents in CGLH, chapter 4 [p. 598]: "I do not have anything to say about the fact that the Jews, because of the musical accent $\sim$, which they call a zarka, now bring in a ga'ya into the syllable antecedent to it, because it is not followed by those who either wish to speak Hebrew or to chant it."

45 The term Qal, used by modern Hebrew grammarians, does not appear in Spinoza's work.

46 Here again, the term niph'al is not used by Spinoza.

47 Spinoza does not use this term. 
On Active Reflexive Verbs (Hithpa'el); [chapter twenty-one] On Passive Reflexive Verbs (Hothpa'al); [chapter twenty-two] On Verbs of the Second Conjugation (ל); [ [chapter twenty-three] On Verbs of the Third Conjugation (ל"ל); [chapter twenty-four] Verbs of the Fourth Conjugation ל"ע ל"ל [chapter twenty-five] Verbs of the Fifth Conjugation (פי); [chapter twentysix] On Composite Verbs from this Fifth and Three Preceding Conjugations; [chapter twenty-seven] On Verbs of the Sixth Conjugation (Ayin Aleph, Ayin Vav, and Ayin Yod); [chapter twenty-eight] Verbs of the Seventh Conjugation (Peh Gutturals); [chapter twenty-nine] Verbs of the Eighth Conjugation (Ayin Gutturals); [chapter thirty] On Defective Verbs; [chapter thirty-one] Another Class of Defectives; [chapter thirty-two] Concerning Deponent Verbs, and Quadrilateral Verbs, and Incidentally Concerning the Composition of Verbs, Modes, and Tenses; [chapter thirty-three] On the Nominative Participle.

The need to produce a Hebrew grammar was an explicit concern of Spinoza's, as shown by the statement appearing twice in the Compendium grammatices linguae hebraeae, that many have written a grammar of the Scriptures, but none has written a grammar of the Hebrew language. ${ }^{48}$ It must be said that an awareness that what survived through the biblical texts was only a partial remnant of what was formerly the Hebrew language existed already among the first Hebrew grammarians of the Middle Ages. This issue was discussed in the tenth century by disciples of Menahem ben Saruq (910/920-970), who lamented the situation of the Hebrew language in their dispute against Dunash ben Labrat (920/925-985) ${ }^{49}$ in Moshe ibn 'Ezra's (1055-1135) poetry treatise Kitâb almuhadara wal-mudkâkara, ${ }^{50}$ and in the second half of the eleventh

48 CGLH, chapter 7 [p. 6o4]: "For, as I said in a word, there are many who wrote a grammar of the Scriptures but none who wrote a grammar of the Hebrew language"; chapter 17 [p. 642]: "To be sure, as we have said, they wrote grammar of the Scriptures, not of the language." Spinoza also tried to explain why this happened: “[...] the difficulties of interpreting Scripture have not arisen from a defect in the powers of the natural light, but only from the negligence (not to say wickedness) of the men who were indifferent to the history of Scripture while they could still construct it," ТтP, chapter 7:112 [p. 186].

49 Talmide Menahem, Tešubot de los díscipulos de Menahem contra Dunaš ben Labrat, ed. and trans. by Santiaga Benavente, rev. by Ángel Saenz-Badillos (Granada: Ediciones de la Universidad de Granada, 1986), 20.

50 Moseh Ibn 'Ezra, Kitâb almuḥadara wal-mudk̂âkkara-Sefer ha-'Yiunim we-ha-Dìunim ('Al ha-Širah ha-'Tbrit), ed. Abraham Shlomo Halkin (Jerusalem: Mekize Nirdamim, 1975), 28a [p. 53]: "Due to the prolonged exile and its duration, the Hebrew language almost disappeared [...] Its remnants are only twenty-four books that barely contain the essentials of the language" [in Hebrew, translation is mine]. 
century in Moshe ibn Chiquitilla's introduction to his translation of the grammatical treatises by Hayyuy (990-1050). ${ }^{51}$

Although Spinoza drew the bulk of his work in Compendium grammatices linguae hebraeae from biblical texts, following Moseh ibn Ezra, ${ }^{52}$ his great innovation was to consider Hebrew as a living, productive language. He created neologisms, words that did not appear in the Bible, contravening the rules that had been repeated for centuries that dictated that he should deviate from biblical language as little as possible.

Spinoza also dealt with the acute question of the part of the language that was least preserved, and which has posed the greatest uncertainty, specifically the correct pronunciation. It was clear to him that it is difficult to reconstruct the pronunciation of Hebrew as it was spoken in biblical times, and that he had to rely on written material. Spinoza was aware of the fact that "the Scriptures were written by men of various dialects, and that now the dialects are not recognizable, namely from which tribe this or that dialect originated. ${ }^{53} \mathrm{He}$ had to rely on pronunciation traditions and the opinions of other grammarians. This resulted in a mixture of Ashkenazic and Sephardic pronunciations, as shown by Anthony J. Klijnsmit. ${ }^{54}$ Spinoza basically considered the Sephardic pronunciation of the consonants to be correct, and the Ashkenazic pronunciation of the vowels to be correct, as described by J. Buxtorf (in the Thesaurus Grammaticus Linguae Sanctae Hebraeae of 1620). He actually confounded two contemporary "dialects," something he warns against when he says: "Letters of the same organ of speech are often substituted one for the other in the Scriptures, and an $\aleph$ for an $\mathcal{\nu}$, a $\varnothing$ for a $\uparrow, \beth$ for $\unlhd, \cup$ for a $ת$, etc. [...] For the Ephraimites everywhere substituted a $\varnothing$ for a $\boldsymbol{E}$, letters which really are from the same organ of speech. Nevertheless, although in Sacred Scripture occasionally one letter is changed

$5^{1} \quad$ Jehuda Hayug, Two Treatises on Verbs Containing Feeble and Double Letters, trans. into Hebrew from the original Arabic by Moses Gikatilla, ed. from Bodleian Mss. with an English trans. by John W. Nutt (London and Berlin: Asher \& Co. 1870), 1: "And forasmuch as no one is left from whom we may learn the properties of the language, and none remaining from whom we may acquire all its meanings, but only what we may understand from the materials afforded in the holy Scriptures, and learn from the prophetical books; though that is but a small portion of the whole, inasmuch as the prophets did not come to employ the language in its full extent, but only so far as they required for their prophecy and vision."

Ibn 'Ezra, Kitâb almuhadara wal-mudk kâkara, 107b [p. 203]: "Everything you find in it [in the Bible], use it, but do not apply analogy to what you cannot find. Wherever language walks, you should walk, and wherever it stops, you should stop; be an imitator, not a creator; a follower, not an inventor" [in Hebrew, translation is mine].

53 CGLH, chap. 2 [p. 590].

54 Anthony J. Klijnsmit, "Spinoza over taal," Studia Rosenthaliana 19 (1985): 10-26. 
for another of the same organ, one may not follow this example. For if it were otherwise, then the dialects would confuse the language." 55

Since it is known that Spinoza attended the school of the Sephardic community in Amsterdam, it is important to know how grammar was taught for a better understanding of his Compendium grammatices linguae hebraeae. More information on the contents of his grammatical treatise, which happens to be much longer than other Hebrew grammars written by his contemporaries, is found in Antony J. Klijnsmit's studies. ${ }^{56}$

In the following paragraphs I would like to present some details on Spinoza's opinion that the existing grammars were unsatisfactory. Apart from the reproaches he made on the contents of the Hebrew grammars that preceded his, there is a formal aspect worth noting: his was the first Hebrew grammar written in Latin by a Jew. It is likely that, as Jelles said, the Compendium grammatices linguae hebraeae was addressed to some of Spinoza's friends who understood Latin and were interested in being able to directly access the biblical text. ${ }^{57}$

Guadalupe González Dieguez shared the general terms by which Spinoza presented a pejorative image of grammarians who preceded him, with an attitude that she rightly noted was clearly controversial. ${ }^{58}$ She shows a recurring identification in the two works which Spinoza specifically dedicated to linguistic issues (Compendium grammatices linguae hebraeae and the Tractatus Theologico-Politicus) between "grammarians," "idle masoretes," "rabbis," and "pharisees." This distinction was made in the texts as follows: "This is the Syriac script which Ezra preferred over the ancient Hebrew letters, and which the Pharisees superstitiously followed in their holy writings. In reality the authors frequently used other scripts." ${ }^{59}$ Spinoza identifies Masoretes, Pharisees, and Grammarians: "Therefore I will leave their minutiae to the Pharisees and idle

55 CGLH, chap. 2 [p. 590]. Actually, in his extensive treatment of Hebrew pronunciation, Spinoza proves himself an eclectic: He describes the pronunciation of the consonants as was common among the Portuguese in his time, and gives the Ashkenazic pronunciation of the vowels.

56 Klijnsmit, "Spinoza over taal," 1-38; id., "Amsterdam Sefardim," 158-63; Klijnsmit, "Some Seventeenth-Century Grammatical Descriptions," 92-96.

57 "The Concise Grammar of the Hebrew Language which is here offered to you, kind reader, the author undertook to write at the request of certain of his friends who were diligently studying the Sacred Tongue, inasmuch as they recognized him rightly as one who had been steeped in it from his earliest youth, was diligently devoted to it for many years afterward, and had achieved a complete understanding of the innermost essence of the language," CGLH, Notice to the Reader, [p. 587].

58 González Dieguez, Baruj Spinoza, 14-17.

59 CGLH, chap. 2 [pp. 589-9o]. 
Masoretes"; "Grammarians who have not understood anything." About the Masoretes he said: "And although these two things, vowels and punctuation marks, are usually replaced with full stops and accents, we cannot trust them, since they were invented and established by men of later times, whose authority should be worthless to us"; "The difficulty of interpreting Scripture has never arisen from the lack of forces of natural light, but only from the negligence, if not the malice, of men who neglected the history of Scripture, while they developed it"; "Clearly the rabbis were completely delirious, and the commentators that I have read, dream, fantasize and even corrupt language itself from its root." ${ }^{\prime 60}$ If Spinoza attributed ignorance and bad faith to rabbis, Pharisees, Masoretes, and Grammarians, he considered Kabbalists (with whom he did not even come into discussion) to be simply crazy, "I've read nothing in their writings which had the air of a secret, but only childish thoughts. I've also read, and for that matter, known personally, certain Kabbalistic triflers. I've never been able to be sufficiently amazed by their madness." ${ }^{61}$

Following González Diéguez, it is interesting to note that zealous advocates of rabbinic orthodoxy, such as Isaac Aboab da Fonseca himself or Menasseh ben Israel, were Spinoza's grammar teachers in the Ets Haim school in Amsterdam. This makes it easier to understand the relationship between Spinoza and Pharisees and the pejorative appellations he uses to identify them in the context between Phariseeism and Sadduceeism, which was somehow recovered and reactivated during those days in the Western Sephardic diaspora.

This naming results from the spiritual crises that arose within the Western Sephardic communities, a phenomena defined by Kaplan as the "intellectual ferment" that led, inter alia, to the excommunication of Uriel da Costa in 1623, Spinoza in 1656 , and Juan de Prado in $1658 .^{62}$ Those Sephardic communities did not grow and develop in an organic way, with each generation passing on the heritage of its ancestors. Among the so-called "New Jews" members of the

6o A similar position was held in the eleventh century by the great Hebrew linguist Jonah ibn Ğanah in Sefer ha-Riqmah (Kitab al-Luma), 11-12: "Those who take this science [grammar] most lightly and despise its problems, are those devoted to the science of the Talmud. They are arrogant because they have very little understanding of it. [...] They belittle this science and yet they learn what they learn in the Talmud in the wrong way, and study what they study incorrectly. [...] For knowledge of inflection and speech is sorcery for them, not far from heresy." [English translation is mine.].

61 TTP, chap. 9:136 [p. 217]. Possibly reference to Isaac Aboab da Fonseca and Menasseh ben Israel, although they would not have been the only Kabbalists in seventeenth-century Jewish Amsterdam.

62 Yosef Kaplan, "The Intellectual Ferment in the Spanish-Portuguese Community of Seventeenth-Century Amsterdam," [Hebrew] in The Sephardic Legacy, ed. Haim Beinart (Jerusalem: Magnes Press, 1992), 288-314. 
Spanish-Portuguese nation, there were individuals and groups who isolated themselves from normative Judaism by refusing to accept the yoke of Jewish law and rabbinic commandments. They also served as a focus of attraction for others who could join them at any time.

By expressing their uncertainties about the divine character of the Oral Law and the rabbinical regulations, those heterodox thinkers, whose approach was essentially individualistic, undoubtedly created an acute problem that disturbed the Sephardic diaspora in Western Europe. Immanuel Aboab wrote his Nomologia o Discursos legales, a comprehensive and detailed praise of the Oral Law, against those of his people already in Venice, between 1616 and 1625:63 "Who say and argue with stiffness of neck that one should not place one's faith in the true interpretation of the holy Torah, received by the ancient sages of Israel and taught by them, claiming that one understands scripture, whose perfection is beyond measure, from within itself, and that all of them will understand it fully with a little bit of study, and that one need merely read it and observe it as it is written." ${ }^{\prime 4}$

This adherence to the literal Scripture, disregard for Jewish Talmudic exegesis of the Bible, and the desire to be freed from the bonds of the "Pharisaic" tradition and customs subjected to the Oral Law, created the impression that this was a kind of Karaism not only at that time, but also in modern research. Although Imanuel Aboab does not use the name Karaites for those denying the Oral Law in his entire apologetic work, ${ }^{65}$ other authors who defended the authority of the rabbinical tradition mention Karaism in their works. However, as Kaplan showed, it was "not in application to any real group acting in the Spanish Portuguese Jewish society of their time."66

It is clear that Spinoza's controversial ideas concerning his Judaism, biblical criticism and interpretations, religious beliefs and practices, including an

63 The reasons for opposition to rabbinical authority in sixteenth- and seventeenth-century Venice originated in ideological difficulties experienced by some of the returning conversos, contemporary skepticism and political maneuvering in the Venetian community. See Moisés Orfali, "Faith and Power in the Struggle over Rabbinic Judaism in Venice during the Baroque Period," [Hebrew] Péamim 8o (Summer 1999): 44-59.

64 Moisés Orfali, ed., Nomología o Discursos Legales de Imanuel Aboab (Salamanca: Ediciones Universidad Salamanca, 2007), 76.

65 Ibid., 36-41.

66 Yosef Kaplan, "Karaites' in the Early Eighteenth Century," in An Alternative Path to Modernity. The Sephardic Diaspora in Western Europe, ed. Yosef Kaplan (Leiden-BostonCologne: Brill, 2000), 247. Kaplan there clarifies the matter: "In the Sephardic Jewish polemic literature of the seventeenth century the concept 'Karaism' had become synonymous with the schismatics and sectarians, and some writers used it as a general term for heresy and blasphemy." 
imaginary Karaism and more, led to his excommunication. ${ }^{67}$ In spite of his controversial opinions of the Hebrew grammarians before him, there are references to "grammarians" throughout the Compendium grammatices linguae hebraeae, where no polemic intent can be assumed. It should be remembered that some of the grammarians before him, such as Moses ibn Ezra, were regarded very highly by Spinoza, and even if he criticizes his predecessors, he makes crucial use of their achievements: he uses the commentaries of Rashi, Abraham ibn 'Ezra, and the grammatical works of the Qimhi and Abraham ben Me'ir de Balmes. ${ }^{68}$

\section{4}

\section{Conclusion}

In this chapter, I chose Aboab da Fonseca and Spinoza's Grammars as examples for showing the object of their grammar books: the Hebrew language or the language of the Scriptures.

Aboab's explicit concern was a need to produce a grammar of the language of the Scriptures in order to teach biblical Hebrew to children and old persons in the growing Jewish community of Dutch Pernambuco in northeast Brazil. He regarded it impracticable to attempt to teach Hebrew grammar in all its details to beginners. It was more profitable to deal with the main principles and uses which should form the basis for more advanced study. Aboab endeavored to avoid, as much as possible and practicable, references to the minute and manifold exceptions that appear in advanced Hebrew grammars.

Contrary to Aboab, Spinoza's aim was to write a grammar of the Hebrew language and not one of the Scriptures as many grammarians before him had done. Because his grammar was also meant to provide active knowledge of Hebrew, it is normative and prescriptive. Since Spinoza's friends, for whom his grammar was meant, were gentiles, he wrote his grammar in Latin, which was the scientific language outside the Jewish community.

67 Asa Kasher and Shlomo Biderman, "Why Was Baruch de Spinoza Excommunicated?" http://www.tau.ac.il kasher/pspin.htm, indicate that it could also have been related to public discussions he may have had on Cartesian philosophy; Cassuto, Spinoza hebraisant, 233: "A mon avis, l'une des raisons profondes de son excommunication réside dans son étude de la lettre, ce qui le fait apparenter au courant hérétique des défenseurs de la Lettre, c'est à dire les Qaraïtes."

68 See, for example, CGLH: chap. 3 [p. 592]; 7 [p. 6o4, the comment there is not in Rashi's commentary but in Ibn Ezra]. 


\section{Bibliography}

Aboab, Isaac. Paráfrasis comentado del Pentateuco. Amsterdam: Iaacob de Cordova $5441[1681]$.

Askénazi, Joël et Ashkénazi-Gerson, Jocelyne. Abrégé de grammaire hébraique. Paris: J. Vrin, $1968^{3}$.

Bodian, Miriam. Hebrews of the Portuguese Nation: Conversos and Community in Early Modern Amsterdam. Bloomington: Indiana University Press, 1997.

Cassuto, Philippe. Spinoza hebraisant L'hebreu dans l'“Tractatus theologico-politicus" et le "Compendim grammatices linguae hebrae." Leuven: Peeters Publishers, 2000.

Den Boer, Harm. La Literatura sefardí de Amsterdam. Alcalá de Henares: Universidad de Alcalá-Instituto de Estudios Sefardíes y Andalusíes, 1995.

Den Boer, Harm. Sephardic Editions, 1550-1820. Spanish and Portuguese Books Written and/or Published by Sephardic Jews of Early Modern Europe. Leiden: Brill, 2003-2005.

Elqayam, Avi. Sabbatean Millenarianism in the Seventeenth Century. A Study of Moshe Abudiente's Fin de los Dias. Los Angeles: Cherub Press, 2014.

Fuks, Lajb, and Renate G. Fuks-Mansfeld. Hebrew and Judaic Manuscripts in Amsterdam Public Collections. II. Catalogue of the Manuscripts of Ets Haim / Livraria Montezinos, Sephardic Community of Amsterdam. Leiden: Brill, 1975.

Giovanni, Licata. "Spinoza e la cognition universalis dell'ebraico. Desmitificazione e speculazione grammaticale nel Compendio di grammatical ebraica." Giornale di Metafisica 31 (2009): 625-61.

González Dieguez, Guadalupe. Baruj Spinoza. Compendio de gramática de la lengua hebrea. Intr., Trad. y notas de González Dieguez, Guadalupe. Madrid: Editorial Trotta, 2005 .

Ibn 'Ezra, Moseh. Kitâb almuhadara wal-mudk̂k̂kara-Sefer ha'Yiunim we-ha-Diyunim ('al ha-Širah ha-'Ibrit). Edited by Abraham Shlomo Halkin. Jerusalem: Mekize Nirdamim, 1975 .

Ibn Ğanah, Jona. Sefer Hariqma (Kitab Al-Luma'). Translated by Jehuda ibn Tibbon. Edited by Michael Vilenski. Berlin: Akademie-Verlag, 1930.

Kaplan, Yosef. "The Intellectual Ferment in the Spanish-Portuguese Community of Seventeenth-Century Amsterdam." In The Sephardic Legacy. Edited by Haim Beinart, 2: 288-314. Jerusalem: Magnes Press, 1992.

Kaplan, Yosef. Judíos nuevos en Amsterdam: Estudios sobre la historia sociale intelectual del judaísmo sefardí en el siglo XVII. Barcelona: Gedisa, 1996.

Kaplan, Yosef. “'Karaites' in the Early Eighteenth Century." In An Alternative Path to Modernity. The Sephardi Diaspora in Western Europe. Pp. 234-79. Leiden-BostonCologne: Brill, 2000.

Kaplan, Yosef. "El perfil cultural de tres rabinos sefardíes a través del análisis de sus bibliotecas." In Familia, Religión y Negocio. El sefardismo en las relaciones entre el mundo 
ibérico y los Países Bajos en la Edad Moderna. Edited by Jaime Contreras, Bernardo J. García García and Ignacio Pulido, 269-86. Madrid-Alcalá de Henares: Fundación Carlos de Amberes, 2002.

Kaplan, Yosef. "The Libraries of Three Sephardic Rabbis in Early Modern Western Europe." [Hebrew] In Libraries and Book Collections. Edited by Yosef Kaplan and Moshe Sluhovsky, 225-6o. Jerusalem: The Shazar Center, 2006.

Kayserling, Meyer. "Isaac Aboab, the First Jewish Author in America." Publications of the American Jewish Historical Society 5 (1897): 124-136, http://jawutrecht.files.word press.com/2012/11/out-26.pdf.

Kayserling, Meyer. “Rabbi Yitzhak Aboab ha-Šeliši." Ha-Goren 3 (1902): 155-74.

Klijnsmit, Anthony J. "Amsterdam Sephardim and Hebrew Grammar in the Seventeenth Century." Studia Rosenthaliana 22 (1988): 144-64.

Klijnsmit, Anthony J. “'Se qual o ouro entre todos os metáis.' Abudiente's Hebrew Grammar (1633)." In Die Sefarden in Hamburg. Zur Geschichte einer Mindehert. Heraugegeben von Michael Studemund Halévy in Verbindung mit Peter Koj, 319-374. Hamburg: Helmut Buske Verlag, 1994.

Klijnsmit, Anthony J. "Some Seventeenth-Century Grammatical Descriptions of Hebrew." Histoire Épistémologie Langage 12, no. 1 (1990): 77-101.

Klijnsmit, Anthony J. "Spinoza over taal." Studia Rosenthaliana 19 (1985): 1-38.

Melammed, Ezra Zion. Mepharshei Hamikra. 2 vols. Jerusalem: Magnes Press 1975.

Offenberg, Adri. "A Mid-Seventeenth-Century Manuscript of the (Unpublished) Hebrew Grammars of Menasseh Ben Israel and Isaac Aboab da Fonseca Recovered." Zutot 3 (2003): 98-107.

Offenberg, Adri. Menasseh ben Israel (1604-1657): Een Biografische Schets. Amsterdam: Menasseh ben Israel Instituut, 2000.

Orfali, Moisés. "Faith and Power in the Struggle over Rabbinic Judaism in Venice during the Baroque Period." [Hebrew] Pe'amim 8o (Summer 1999): 44-59.

Orfali, Moisés. Isaac Aboab da Fonseca:Jewish Leadership in the New World. Eastbourne: Sussex Academic Press, forthcoming.

Orfali, Moisés. "Observaciones sobre el Paráfrasis comentado del Pentateuco de R. Isaac Aboab da Fonseca y sus fuentes" eHumanista 20 (2012): 215-38.

Orfali, Moisés. "Paraphrastic Commentary to the Pentateuch by Isaac Aboab da Fonseca." In Portuguese Jews, New Christians and "New Jews": A Tribute to Roberto Bachmann. Edited by Bruno Feitler and Claude Stuczinsky, 334-6o. Leiden-Boston: Brill, 2018.

Orfali, Moisés, ed. Nomología o Discursos Legales de Imanuel Aboab. Salamanca: Ediciones Universidad Salamanca, 2007.

Pieterse, W. Chr. Daniel Levi de Barrios als geschiedschrijver van de PortugueesIsraelietiche Gemeente te Amsterdam in zijn "Triumpho del Govierno Popular." Amsterdam: Scheltema \& Holkema NV, 1968. 
Rubin, Solomon. Compendium grammatices Linguae Hebraeae. Podgórze-Krakow: Drukiem I nakladem Józefa Plessnera i Ski., 1905.

Sáenz Badillos, Ángel. "David de Cohen Lara y sus dos vocabularios rabínicos." In Los Judaizantes en Europa y la Literatura Castellana del siglo de Oro. Edited by Fernando Díaz Esteban, 341-49. Madrid: Letrúmero, 1994.

Silva Rosa, Jacob S. da. "Iets over den Amsterdamschen Opperabijin Isaäc Aboab." Centraalblad voor Israelieten in Nederland 29 (1913): nos. 39-41.

de Spinoza, Benedict. Compendium grammatices linguae hebrae, in Spinoza. Complete Works. With translations by Samuel Shirley, edited with introduction and notes by Michael L. Morgan. Indianapolis-Cambridge: Hackett Publishing Company, 2002.

de Spinoza, Benedict. De Nagelate Schriften van B.D.S. als Zedekunst, Staat-kunde, Verbetering van 't verstand, Brievben en Antwoorden uit Verscheide Talen in de Nederlandesche Gebracht. Amsterdam: Jan Rieuwertsz, 1677.

de Spinoza, Benedict. Tractatus Theologico-Politicus, in The Collected Works of Spinoza. Translated and edited by Edwin Curley. Princeton, NJ: Princeton University Press, 2016.

Wiznitzer, Arnold. "The Minute Book of Congregations Zur Israel of Recife and Magen Abraham of Mauricia, Brazil." Publications of the American Jewish Historical Society 42 (1953): 217-302.

Wiznitzer, Arnold. Jews in Colonial Brazil. New York: Columbia University Press, 1960. Yerushalmi, Yosef Hayim. "The Re-education of Marranos in the Seventeenth Century." In The Third Annual Rabbi Louis Feinberg Memorial Lecture in Judaic Studies, March 26, 1980. Pp. 7-11. Cincinnati: University of Cincinnati, 1980.

Yerushalmi, Yosef Hayim. From Spanish Court to Italian Ghetto. Isaac Cardoso-A Study in Seventeenth-Century Marranism and Jewish Apologetics. Seattle and London: University of Washington Press, 1981.

Yerushalmi, Yosef Hayim. "Connaisance du judaïsme et préparation spirituelle chez les marranes revenues au judaïsme au cours du XVII' siècle." In Sefardica. Essais sur l'histoire des juifs, des marranes \& des nouveaux-chrétiens d'origine hispanoportugaise. Pp. 235-54. Paris: Chandeigne, 1998. 